\title{
IgE class immune complexes in Felty's syndrome: characterisation of antibody activities in isolated complexes
}

\author{
K. MERÉTEY,${ }^{1}$ A. FALUS,${ }^{1}$ U. BÖHM ${ }^{1}$ H. PERMIN,$^{2}$ AND A. WIIK ${ }^{2}$ \\ From the ${ }^{1}$ National Institute of Rheumatology and Physiotherapy, Budapest, Hungary, and the ${ }^{2}$ University \\ Clinic for Infectious Diseases, Rigshospitalet, Copenhagen, Denmark
}

SUMMARY By means of a double polyethylene glycol (PEG) precipitation and PRIST technique IgE was detected in 3\% PEG precipitates and in the immune complex enriched fractions purified by solid-phase $\mathrm{C} 1 \mathrm{q}$ adsorption from sera of 11 of 20 patients with Felty's syndrome. No correlation was found between the occurrence of complexed $\mathrm{IgE}$ and total protein content of the immune complex enriched material. IgE rheumatoid factor and anti-IgE antibody activity were detected in some of the immune complex fractions. Serum levels of complement C3, C4, and factor B were low in IgE immune complex positive cases. Only 4 of 20 patients with articular rhe umatoid arthritis had IgE-containing immune complexes.

Felty's syndrome (FS) designates a specific association of symptoms including rheumatoid arthritis (RA), leucopenia, splenomegaly, and frequently lymphadenopathy. One of the most extensively studied laboratory features of this disease is the appearance of granulocyte-specific antinuclear antibodies of all 5 immunoglobulin (Ig) classes and often cytoplasmic Ig inclusions in circulating polymorphonuclear leucocytes of these patients. ${ }^{1-3}$ High levels of circulating immune complexes (IC) are also frequently found.$^{4-6}$.

When an interpretation of the cause of the leucopenia in FS is attempted, the overloading of neutrophils by IC leading to removal of these cells from circulation is favoured by many. In this work we describe the existence of circulating IC containing $\mathrm{IgE}$ and certain IgE-related autoantibodies in FS.

\section{Materials and methods}

Controls and patients. Twenty control persons, 20 patients, with classical RA according to the American Rheumatism Association criteria, and 20

Accepted for publication 10 May 1983.

Correspondence to. Dr K. Merétey, National Institute of Rheumatology and Physiotherapy, Laboratory of Immunology, Budapest II, Frankel Leó u. 17-19, 1525 Budapest, Hungary. patients with FS showing leucopenia $\left(0 \cdot 8-4 \cdot 3 \times 10^{9} / 1\right)$ and neutropenia $\left(0 \cdot 1-1 \cdot 4 \times 10^{9} / 1\right)$ were selected. All FS patients had splenomegaly at the time of investigation. Sera obtained from the patients were stored at $-30^{\circ} \mathrm{C}$ until studied. FS patients were 15 women and 5 men with a mean age of 65 years (range 46-76). The duration of the articular disease was from 1 to 30 years (mean 14 years). The RA patients and controls were matched as to sex and age (mean age 52 years, range 33-73, 14 women and 6 men, mean duration of disease 8 years, range $1-20$ years).

Detection of IgE in IC enriched fractions. ICenriched material was isolated by precipitation of $1 / 50$ diluted serum samples by $3 \%$ polyethyleneglycol (PEG) 6000 (Merck) solution as described by Creighton et al. ${ }^{7}$ The protein content was determined according to Lowry et al. ${ }^{8}$ The presence of IgE in redissolved (phosphate buffered saline (PBS), $\mathrm{pH}$ 7.4) PEG fractions was detected either by the paper radioimmunosorbent test (PRIST) technique (Phadebas, Pharmacia, Sweden) or by means of a double PEG precipitation assay developed in our laboratory. ${ }^{9}$ Briefly, $50 \mu \mathrm{l}$ of the redissolved PEG precipitates were incubated with $50 \mu$ l of ${ }^{125}$ I-sheep antihuman IgE (Phadebas RAST Isotope Unit, Pharmacia, Sweden). The labelled anti-IgE bound to the IC was precipitated again by $3 \%$ PEG, and the pellet was counted for radioactivity (Autogamma 
Counter, Gamma Works, Hungary). Pellets with more than $3 \%$ of the added radioactivity were considered positive.

All batches of ${ }^{125-}$ I anti-IgE were tested with rheumatoid factor (RF)-containing IgE negative PEG fractions to exclude the nonspecific binding of the labelled antibody to RF.

Measurement of IgE in IC purified on particlebound Clq. IC were also isolated by adsorption to particle-bound $\mathrm{C} 1 \mathrm{q}$ as described by Farrel et al. ${ }^{10}$ Plastic particles (Biosilon) were coated by purified $\mathrm{C} 1 \mathrm{q}(50 \mu \mathrm{g} / \mathrm{ml}$ to $100 \mathrm{mg}$ particles $)$ and incubated with $100 \mu$ l of serum sample in the presence of 0.05 $\mathrm{M} \mathrm{NaCl}$ solution ( $\mathrm{pH} 7 \cdot 2$ ) containing $0 \cdot 1 \%$ Tween 20. After an overnight rotation at room temperature the particles were washed 3 times by $0.05 \mathrm{M} \mathrm{NaCl}$. IC was desorbed by adding $100 \mu \mathrm{l}$ of $1.5 \mathrm{M} \mathrm{NaCl}(\mathrm{pH}$ 8.0) and subsequent incubation at room temperature for $30 \mathrm{~min}$. Fractions were dialysed against an excess

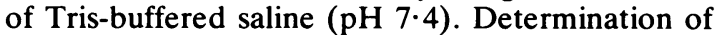
IgE in IC was performed by the PRIST technique.

Detection of IgE rheumatoid factors $(R F)$ in PEG fractions and sera. A solid-phase immunosorbent was prepared from rabbit IgG bound to cyanogen bromide activated Sephadex gel and used for isolation of RF. (The immunosorbent was prepared and kindly given to us by F. Peterfy, 'HUMAN' Institute for Sera and Vaccine Production, Budapest.) Borate buffer, $\mathrm{pH} 8 \cdot 2$, was used supplemented by $5 \%$ bovine serum albumin (BSA) for every step of the experiment. Packed immunosorbent was suspended and was distributed into vials under constant stirring. PEG fraction or 1:5 diluted sera were added to the tubes containing the immunosorbent. After 2 hours' incubation at room temperature the free proteins were washed off with PBS and the amount of IgE RF activity was determined by subsequent binding of ${ }^{125-}$ I-anti-IgE antibodies of sheep origin. The bound radioactivity was determined and the count per minute (c.p.m.) values evaluated by deduction of the c.p.m. values obtained using only the immunosorbent and the buffer during the first incubation.

Higher binding than $1 \cdot 1 \%$ of the total activity was considered to be a positive result. ${ }^{11}$

IgE binding activity in sera and PEG fractions. In preliminary experiments it was proved that heat treatment $\left(56^{\circ} \mathrm{C}, 240 \mathrm{~min}\right)$ of sera destroys most of the antigen determinants important for immunochemical detection of IgE by the Phadebas PRIST test for IgE (Merétey et al., in preparation). We incubated the sera or the redissolved PEG precipitates at $56^{\circ} \mathrm{C}$ for $240 \mathrm{~min}$, the samples were diluted 1:2 with a standard amount (10 kIU) of IgE (from the Phadebas IgE kit), and the mixture was incubated overnight at $4^{\circ} \mathrm{C}$. The difference in the quantity of available $\operatorname{IgE}$ by incubation with the in- activated samples is taken as denoting presence of IgE-binding activity. More than a $1 \mathrm{kIU}$ decrease in the measured IgE was considered to be a positive indicator of anti-IgE activity (precision of IgE measurement was $5 \%$ ).

Measurement of IgE, C3, C4, and factor B levels in sera of patients. IgE levels of sera were determined by the Phadebas PRIST test (Pharmacia). Complement factor levels (C3, C4, and B) were measured by means of the Laurell rocket electrophoresis ${ }^{12}$ using specific immune sera (Behringwerke).

Statistics. The 2-tailed Student's $t$ test was used and the level of significance set at $5 \%$.

\section{Results}

Occurrence of IgE in isolated PEG fractions detected by double PEG precipitation assay. Eleven PEG fractions from sera of 20 FS patients showed more than $3 \%$ binding of labelled anti-IgE compared with the normal control group (no positives among 20 samples) and the RA group (4 positives out of 20 investigated) (Table 1). If the mean values are compared the differences are highly significant $(p<0.01$ and $<0.05$ respectively).

Detection of IgE by PRIST technique in redissolved $P E G$ precipitates and in purified IC fractions desorbed from solid-phase C1q. IgE was found in 5 preselected PEG fractions and in 6 of $20 \mathrm{C} 1 \mathrm{q}$ purified IC of FS patients by the Phadebas PRIST test (Table 2). Interestingly, in 2 patients the C1qpurified IC fraction contained measurable quantities of $\operatorname{IgE}$, though we failed to detect IgE among the components of $3 \%$ PEG precipitable complexes of the same sera.

The level of IgE detected either by double PEG precipitation technique or by PRIST assay in PEG fractions showed no correlation with the serum IgE concentration of the given samples. Similarly the

Table 1 IgE in PEGfractions from sera

\begin{tabular}{lllll}
\hline $\begin{array}{l}\text { Patient } \\
\text { group }\end{array}$ & $n$ & $\begin{array}{l}\text { Fractions* } \\
\text { positive } \\
\text { (no.) }\end{array}$ & $\begin{array}{l}\text { Mean } \\
\text { SEM } \\
(\%)\end{array}$ & $p^{\dagger}$ \\
\hline $\begin{array}{c}\text { Felty's } \\
\text { syndrome }\end{array}$ & 20 & 11 & $5.61 \pm 1.49$ & $<0.05$ \\
$\begin{array}{c}\text { Rheumatoid } \\
\text { arthritis }\end{array}$ & 20 & 4 & $2.29 \pm 0.21$ & $<0.01$ \\
$\begin{array}{c}\text { Controls } \\
20\end{array}$ & 0 & $1.64 \pm 0.18$ & \\
\hline
\end{tabular}

* More than $3 \%$ of added ${ }^{125-}$ - I-anti-IgE antibody was bound to PEG fraction as shown by the double PEG precipitation assay.

+ Student's $t$ test. 
Table 2 IgE in PEG fractions and in C1q purified IC fractions of sera from Felty's syndrome patients determined by the PRIST assay

\begin{tabular}{|c|c|c|c|}
\hline Fraction & $n$ & $\begin{array}{l}\text { Positive* }^{*} \\
\text { (no.) }\end{array}$ & $\begin{array}{l}\text { Concentration } \\
(k I U)^{\dagger}\end{array}$ \\
\hline $\begin{array}{l}\text { 3\% PEG IC } \\
\text { Solid-phase C1q IC }\end{array}$ & $\begin{array}{r}5 \\
19\end{array}$ & $\begin{array}{l}5 \\
6\end{array}$ & $\begin{array}{l}2 \cdot 08 \pm 0 \cdot 18 \\
0 \cdot 76 \pm 0.06\end{array}$ \\
\hline
\end{tabular}

* $0.5 \mathrm{kIU}$ IgE in the IC fraction.

+ Mean \pm SEM of the positive samples.

amount of complexed IgE did not parallel the total protein content of $3 \%$ PEG precipitable material.

Detection of IgE class RF (anti-rabbit IgG) in sera and PEG fractions. Six isolated PEG fractions contained measurable quantities of IgE class RF activity (Table 3). In 4 cases a high level of IgE RF was revealed in the sera too. No correlation with total IgE levels was demonstrated.

Measurement of anti-IgE activity in sera and PEG fractions. IgE binding activity could be measured in 11 of 20 sera and in 3 of 20 PEG fractions of FS patients (Table 3). No relation with the IgE level of the same serum or PEG fraction was found.

Levels of C3, C4, and factor B in sera of IgE ICpositive and -negative patients. The comparison of IgE IC-positive and -negative samples revealed that the protein levels of PEG fractions did not differ significantly from each other (Table 4). However, in samples with IgE IC positivity a decreased $\mathrm{C} 4$ concentration was detected, and in this respect a highly significant difference was found between the $\operatorname{IgE}$ IC-positive and -negative samples. The C4 levels were also significantly lower than the normal range of $\mathrm{C} 4$ values. The $\mathrm{C} 3$ and factor $\mathrm{B}$ values were in $\mathrm{IgE}$ IC-positive sera significantly lower than those of IgE IC-nagative ones $(\mathrm{p}<0 \cdot 05)$.

Eight serum samples from which C1q purified IC fractions were studied were similarly compared as regards serum complement factor levels (Table 5). The 5 samples without IgE IC contained normal levels of $\mathrm{C} 3, \mathrm{C} 4$, and factor $\mathrm{B}$, but in $3 \mathrm{IgE}$ ICpositive samples the levels of complement factors studied were reduced. The most striking differences were found in $\mathrm{C} 3$ and factor $\mathrm{B}$ concentrations.

Relation to circulating leucocyte and granulocyte counts. At the time of the collection of blood samples all patients were leucopenic and granulocytopenic. The 11 IgE IC-positive patients had significantly higher leucocyte counts $\left(2 \cdot 07 \times 10^{9} / 1\right)$ than the $\mathrm{IgE}$ IC-negative group $\left(1.41 \times 10^{9} / 1\right)(p<0 \cdot 05)$.

\section{Discussion}

Nowadays the physiological and pathological significance of antibodies of the IgE class seems to exceed the sphere of the atopic diseases. IgE class rheumatoid factors, ${ }^{12-15}$ nonorgan-specific and granulocyte-specific antinuclear antibodies, ${ }^{316}$ and

Table 3 IgE RF and IgE binding activities in IC fractions of Felty's syndrome patients

\begin{tabular}{|c|c|c|c|c|c|c|c|c|c|}
\hline \multirow[t]{3}{*}{ Double PEG test } & \multirow[t]{3}{*}{$n$} & \multirow{2}{*}{\multicolumn{2}{|c|}{$\frac{\operatorname{IgE} R F}{P E G \text { fraction }}$}} & \multirow{2}{*}{\multicolumn{2}{|c|}{$-\frac{\operatorname{IgE} R F}{\text { Sera }}$}} & \multirow{2}{*}{\multicolumn{2}{|c|}{$-\frac{\text { Anti-IgE }}{P E G \text { fraction }}$}} & \multicolumn{2}{|c|}{ Anti-IgE* } \\
\hline & & & & & & & & Ser & \\
\hline & & + & - & + & - & + & - & + & - \\
\hline $\begin{array}{l}\text { IgE IC pos. } \\
\text { IgE IC neg. }\end{array}$ & $\begin{array}{r}11 \\
9\end{array}$ & $\begin{array}{l}6 \\
0\end{array}$ & $\begin{array}{l}5 \\
9\end{array}$ & $\begin{array}{l}4 \\
1\end{array}$ & $\begin{array}{l}5^{\dagger} \\
8\end{array}$ & $\begin{array}{l}2 \\
1\end{array}$ & $\begin{array}{l}9 \\
8\end{array}$ & $\begin{array}{l}7 \\
4\end{array}$ & $\begin{array}{l}4 \\
5\end{array}$ \\
\hline
\end{tabular}

* For limits of positivity see 'Materials and methods'.

† Two sera were not tested.

Table 4 IC and complement levels in IgE IC positive and negative Felty patient sera

\begin{tabular}{|c|c|c|c|c|c|}
\hline & $n$ & $\begin{array}{l}\text { Protein } \\
\text { content } \\
\text { of IC } \\
(m g / l)\end{array}$ & $\begin{array}{l}\text { C4 } \\
\text { conc.* } \\
(m g / l)\end{array}$ & $\begin{array}{l}\text { C3 } \\
\text { conc. } \\
(g / l)\end{array}$ & $\begin{array}{l}\text { Factor } B \\
\text { conc. }^{*} \\
(\mathrm{~g} / \mathrm{l})\end{array}$ \\
\hline Double PEG precipitation assay: + & $\begin{array}{l}6 \\
6\end{array}$ & $\begin{array}{l}411 \pm 183 \\
173 \pm 31\end{array}$ & $\begin{array}{l}0 \cdot 10 \pm 0 \cdot 01 \dagger \\
0 \cdot 26 \pm 0 \cdot 04\end{array}$ & $\begin{array}{l}0 \cdot 80 \pm 0 \cdot 177^{\dagger} \\
1 \cdot 33 \pm 0 \cdot 20\end{array}$ & $\begin{array}{l}0 \cdot 24 \pm 0 \cdot 06^{\dagger} \\
0 \cdot 40 \pm 0 \cdot 05\end{array}$ \\
\hline Student's $t$ test (p) & & NS & 0.0025 & 0.05 & 0.05 \\
\hline
\end{tabular}

* Normal levels: $C 4=0 \cdot 31 \pm 0 \cdot 02 ; C 3=1 \cdot 34 \pm 0 \cdot 03 ; B=0 \cdot 37 \pm 0 \cdot 01(\mathrm{~g} / 1)$.

$\dagger \mathrm{p}$ Values compared with normals: C3, p<0.0025; C4, p<0.0005; B, p<0.025. 
Table 5 Serum complement levels of patients having IgE-containing IC using solid phase Clq adsorption

\begin{tabular}{|c|c|c|c|c|c|}
\hline & $n$ & $\begin{array}{l}\text { Protein } \\
\text { content } \\
\text { of IC } \\
(\mathrm{mg} / \mathrm{l})\end{array}$ & $\begin{array}{l}\text { C4 } \\
\text { conc. } \\
(g / l)\end{array}$ & $\begin{array}{l}\begin{array}{l}C 3 \\
\text { conc.* }\end{array} \\
(\mathrm{g} / \mathrm{l})\end{array}$ & $\begin{array}{l}\text { Factor B } \\
\text { conc. }\end{array}$ \\
\hline IgE IC in $\mathrm{C} 1 \mathrm{q}$ fraction & $\begin{array}{l}3 \\
5\end{array}$ & $\begin{array}{l}255 \pm 74 \\
176 \pm 38\end{array}$ & $\begin{array}{l}0 \cdot 12 \pm 0.03 \\
0 \cdot 28 \pm 0.05\end{array}$ & $\begin{array}{l}0 \cdot 61 \pm 0 \cdot 14 \\
1 \cdot 47 \pm 0 \cdot 2\end{array}$ & $\begin{array}{l}0.14 \pm 0.04 \\
0.45 \pm 0.05\end{array}$ \\
\hline Student's $t$ test (p) & & NS & 0.05 & 0.0125 & 0.005 \\
\hline
\end{tabular}

* Normal levels: $\mathrm{C} 4=0 \cdot 31 \pm 0 \cdot 02 ; \mathrm{C} 3=1 \cdot 34 \pm 0 \cdot 03 ; \mathrm{B}=0 \cdot 37 \pm 0 \cdot 01(\mathrm{~g} / \mathrm{l})$.

bacterial antibodies ${ }^{17}{ }^{18}$ have also been detected in a wide range of nonallergic disorders, suggesting a more general function for IgE.

Participation of IgE among free and IC-bound autoantibodies has been previously described not only in asthma and food allergy ${ }^{19}{ }^{20}$ but also in RA and in SLE. ${ }^{31315}$ According to our present data the frequency of IgE complexes is surprisingly high in FS compared with articular RA and normal controls. These results compare both in frequency and concentration with the IgE complexes of RA patients having other extra-articular manifestations. ${ }^{13}$ Interestingly, the double PEG precipitation method seems to be more sensitive than the PRIST method in demonstrating IgE in PEG fractions. Obviously the $3 \%$ PEG solution does not precipitate all of the IgE complexes, as in 2 serum samples the IgE complexes were detectable only in IC fractions obtained by particle-bound C1q. As in our previous studies ${ }^{9}$ we have not found any correlation between total serum levels and IC-bound IgE.

IgE class RF were found in 5 sera of FS patients investigated. We frequently found heat resistant anti-IgE activity both in sera and in IC ( 11 sera and 3 PEG fractions). The principle of anti-IgE determination is based on an assumption that practically all $\operatorname{IgE}$ molecules in samples are immunochemically destroyed during the $56^{\circ} \mathrm{C}$ incubation for 4 hours and antigenic determinants of exogenously added new $\mathrm{IgE}$ may be bound by antibodies retaining their binding capacity for IgE. ${ }^{13}$

Williams et al. ${ }^{21}$ detected in normal sera anti-IgE antibodies as natural antibodies of IgM class. IgG type autoantibody directed against $\operatorname{lgE}$ was also demonstrated in allergic and control sera by Inganäs et al. ${ }^{22}$ In PEG fractions from extra-articular RA cases the anti-IgE activity was found mostly in the IgG class. ${ }^{13}$ Natural anti-IgE antibodies of IgM class do not cause release of histamine. ${ }^{21}$ We do not know whether the anti-IgE antibodies present in FS patients are active in a histamine releasing system or not. IgE binding factors probably participate in the formation of macromolecular IgE complexes. ${ }^{23}$ This may have caused underestimation of $\operatorname{IgE}$ in the present study.

Whether IgE class autoantibodies, anti-IgE factors, and the consequent formation of IgE complexes are the result of a permanent polyclonal activation in FS or an anomaly of the separate regulation of IgE production and metabolism in FS is unknown. These are questions for further study.

The significance of IgE-mediated mechanisms for the deposition of immune complexes in tissues was originally suggested by Cochrane. ${ }^{24}$ The locally induced inflammation caused by vasoactive mediators enhances the permeability of the capillaries, thereby forming predilection sites for the deposition of other immune complexes. This mechanism may be operative at sites where many basophils or mast cells are present.

IC in the circulation of FS patients strongly interact with neutrophils and are hence ingested. Thereby the IC may contribute to the impaired function of granulocytes. ${ }^{4-6}{ }^{25}$ However, IgE is not a prominent constituent in IC ingested by normal neutrophils from sera of FS patients (Permin and Wiik, unpublished data).

The degranulation of mast cells and basophils coated by IgE having RF activity by IgG-containing IC helps our understanding of the possible pathogenetic role of such IC, since mediators of type I inflammatory reactions may augment systemic IC deposition. ${ }^{24}$ This is in harmony with the fact that FS patients often have a number of extra-articular symptoms. The presence in serum of autoantibodies with anti-IgE activity in free or in complexed form may bind to IgE on the surface of basophils and mast cells, possibly causing degranulation or altering the threshold for degranulation.

We suppose that in some patients chronic immune responses take place where IgE class antibodies are being produced, and often circulate in complexed form possibly similar to what has been found in chronic schistosomiasis. ${ }^{26}$ Since RA patients treated with gold frequently develop antigold antibodies of the IgE class, ${ }^{27}$ it is possible that drug-induced anti- 
bodies also participate in the IgE IC. However, IgE IC-positive cases in our material were mostly not on gold treatment, and so this hypothesis does not explain our findings.

A strik ing correlation was found between the presence of IgE IC and decreased serum complement levels. Decreased C4 levels correlated with $\mathrm{IgE}$ positivity in the PEG fractions, while $\mathrm{C} 4, \mathrm{C} 3$, and factor B levels were low in patients having IgE IC as shown by $\mathrm{Clq}$ adsorption. This suggests that in the latter group the activation and consumption of the complement system was more pronounced. The factors determining the differences among the IC isolated by $\mathrm{PEG}$ precipitation and by $\mathrm{C1} \mathrm{q}$ adsorption as regards complement activation and consumption have not been studied yet.

This study was supported by the Danish National Association Against Rheumatic Diseases.

\section{References}

1 Hurd E R, Andreis M, Ziff M. Phagocytosis of immune complexes by polymorphonuclear leukocytes in patients with Felty's syndrome. Clin Exp Immunol 1977; 28: 413-25.

2 Gupta R C, LaForce F M, Mills D M. Polymorphonuclear inclusions and impaired bacterial killing in patients with Felty's syndrome. J Lab Clin Med 1976; 88: 183-6.

3 Permin H, Wiik A. The prevalence of IgE antinuclear antibodies in rheumatoid arthritis and systemic lupus erythematosus. Acta Pathol Microbiol Scand (C) 1978; 86: 245-9.

4 Hurd E R, Chubik A, Jasin H E, Ziff M. Increased C1q binding immune complexes in Felty's syndrome. Arthritis Rheum 1979; 22: 697-702.

5 Wiik A. Circulating immune complexes involving granulocytespecific antinuclear factors in Felty's syndrome and rheumatoid arthritis. Acta Pathol Microbiol Scand (C) 1975; 83: 354-64.

6 Falus A, Wiik A, Permin H, Brandslund I, Svehag S-E. High serum beta-2-microglobulin $(\beta 2 \mathrm{~m})$ level and circulating immune complexes in Felty's syndrome containing $\beta 2 \mathrm{~m}$ and anti- $\beta 2 \mathrm{~m}$ antibodies. Arthritis Rheum in press.

7 Creighton D W, Lambert P H, Miescher P. Detection of antibodies and soluble antigen-antibody complexes by precipitation with polyethyleneglycol. J Immunol 1973; 111: 1219-27.

8 Lowry O H, Rosebrough N J, Farr A L, Randall R J. Protein measurement with the Folin phenol reagent.J Biol Chem 1951; 193: 265-275.

9 Merétey K, Böhm U, Falus A, Bozsóky S. Radioimmune double PEG precipitation technique for detecting complexed IgE. J Immunol Methods 1979; 26: 223-8.
10 Farrel C, Bloth B, Nielsen H, Daugharty H, Lundmann T, Svehag S-E. A survey for circulating immune complexes in patients with acute myocardial infarction. Use of a Clq binding assay with soluble protein $\mathrm{A}$ as indicator. Scand $\mathrm{J}$ Immunol 1977; 6: 1233-40.

11 Laurell C B. Quantitative estimation of proteins by electrophoresis in agarose gel containing antibodies. Anal Biochem 1966; 15: 45-52.

12 Mizushima Y, Hoshi K, Shoji Y. IgE rheumatoid factor in a case of rheumatoid arthritis with pleuritis. J Rheumatol 1981; 8: 299-302.

13 Merétey K, Falus A, Erhardt C C, Maini R N. IgE and IgE rheumatoid factors in circulating immune complexes in rheumatoid arthritis. Ann Rheum Dis 1982; 41: 405-8.

14 Zuraw B L, O'Hair C H, Vaughan J H, Mathison D A, Curd J G, Katz D H. Immunoglobulin E-rheumatoid factor in the serum of patients with rheumatoid arthritis, asthma, and other diseases.J Clin Invest 1981; 68: 1610-3.

15 Permin H, Egeskjold E-M. IgE anti-IgG antibodies in patients with juvenile and adult rheumatoid arthritis including Felty's syndrome. Allergy 1982; 37: 421-7.

16 Barone C, Bartolini C, Gentiloni N, Grieco A, Flamini G. Systemic lupus erythematosus with only IgE-class anti-nuclear antibodies. Arthritis Rheum 1981; 24: 1441-3.

17 Berger M, Kirkpatrick Ch H, Goldsmith P K, Gallin J I. IgE antibodies to Staphylococcus aureus and Candida albicans in patients with the syndrome of hyperimmunoglobulin $E$ and recurrent infections. J Immunol 1980; 125: 2437-43.

18 Escande A, Serre A. Anti-brucella IgE antibodies in the course of human brucellosis and after specific vaccination. Ann Immunol (Paris) 1981; 132: 257.

19 Brostoff J, Johns P, Stanworth D R. Complexed IgE in atopy. Lancet 1977; ii: 741-2.

20 Brostoff J, Carini C, Wraight D G. Immunological evidence for IgE complexes following food challenge in atopics. Int Arch Allergy Appl Immunol 1981; 66 (suppl 1): 87-8.

21 Williams R C Jr, Griffith R W, Emmons J D, Field R C. Naturally occurring human antiglobulins with specificity for gamma $\mathrm{E}$. J Clin Invest 1972; 51: 955-63.

22 Inganäs M, Johansson, S G O, Bennich $\mathrm{H}$. Anti-IgE antibodies in human serum: occurrence and specificity. Int Arch Allergy Appl Immunol 1981; 65: 51-61.

23 Ishizaka $\mathrm{K}$. Possible approaches to turn of the IgE response. Ann Allergy 1982; 48: 320-4.

24 Cochrane C G. Initiating events in immune complex injury. In: Amos B, ed. Progress in immunology. New York: Academic Press, 1971; 143-53.

25 Howe G B, Fordham J N, Brown K A, Currey H L F. Polymorphonuclear cell function in rheumatoid arthritis and in Felty's syndrome. Ann Rheum Dis 1981; 40: 370-5.

26 Bout D, Santoro F, Carlier Y, Bina J C, Capron A. Circulating immune complexes in schistosomiasis. Immunology 1977; 33: 17-22.

27 Bretza J, Wells I D, Novey H S. Prevalence of IgE antibodies to gold salts in rheumatoid arthritis. Clin Res 1980; 28: 341 A. 